\title{
KAJIAN MUTU IKAN CAKALANG (Katsuwonus Pelamis L.) ASAP UTUH YANG DIKEMAS VAKUM DAN NON VAKAUM SELAMA PROSES PENYIMPANAN PADA SUHU RUANG
}

\author{
Tri Sutrisno Paputungan, Djuhria Wonggo, Lena J. Damongilala
}

Fakultas Perikanan dan Ilmu Kelautan, Universitas Sam Ratulangi, Manado, Sulawesi Utara.

\begin{abstract}
ABSTRAK
Penelitian ini bertujuan untuk mengetahui kemunduran mutu kimiawi dan tingkat kesukaan konsumen ikan Cakalang (Katsuwonus pelamis L.) asap utuh yang dikemas vakum dan non vakum selama 0 hari, dan 2 hari, dengan penyimpanan pada suhu ruang. Metode yang digunakan dalam penelitian ini adalah metode Eksploratif deskriptif, yaitu mengumpulkan data fakta yang telah tersedia dilapangan melalui pencatatan dan pengamatan secara terperinci kemudian dilakukan analisa data berdasarkan data kualitatif dan data kuantitatif. Parameter yang di uji adalah kadar Air, pH, TVB-N, TPC dan Organoleptik.

Hasil penelitian ini menujukkan bahwa Nilai kadar air ikan cakalang (Katsuwonus pelamis L.) asap utuh yang dikemas vakum pada penyimpanan 0 hari memiliki nilai tertinggi yaitu $68.1 \%$ dan non vakum $63.3 \%$ sedangkan pada penyimpanan 2 hari mengalami penurunan untuk ikan yang divakum memiliki nilai $65.6 \%$ dan untuk ikan yang dikemas non vakum yaitu $63.3 \%$.Nilai pH ikan cakalang (Katsuwonus pelamis $L$ ) asap utuh yang disimpan dengan pengemas vakum dan non vakum untuk 0 hari masi baik untuk vakum yaitu 5.68 , dan non vakum 5.85 sedangkan untuk nilai pH pada hari ke 2 vakum 6.12 dan untuk non vakum adalah 6.08. Nilai TVB-N ikan cakalang (Katsuwonus pelamis L) asap utuh yang disimpan dengan pengemas vakum dan non vakum untuk 0 hari yaitu, vakum $39.9 \mathrm{mg} \mathrm{N} / 100$ gr dan non vakum $35.7 \mathrm{mg} \mathrm{N} / 100$ gr sedangkan untuk penyimpanan pada 2 hari mengalami kenaikan yaitu, vakum $85.3 \mathrm{mg} \mathrm{N} / 100 \mathrm{gr}$ dan non vakum $58 \mathrm{mg} \mathrm{N} / 100 \mathrm{gr}$. Nilai TPC ikan cakalang (Katsuwonus pelamis $L$ ) asap utuh yang disimpan dengan pengemas vakum dan non vakum untuk 0 yaitu vakum $49,5 \times 10^{1}$ dan non vakum $74,5 \times 10^{3}$. sedangkan untuk nilai TPC pada hari ke 2 yaitu, vakum $145 \times 10^{1}$ dan non vakum $246,5 \times 10^{1}$. Berdasarkan hasil uji organoleptik ikan cakalang (katsuwonus pelamis L) asap utuh yang dikemas vakum dan non vakum di uji dari segi kenampakan, rasa, dan bau, ikan cakalang asap yang dikemas vakum dan non vakum pada penyimpanan 0 hari memiliki nilai yang baik, sedangkan untuk pengujian hari ke 2 memiliki penurunan nilai. Penyimpanan ikan dengan menggunakan plastik vakum memiliki nilai lebih baik dari ikan yang tidak divakum ini terbukti adanya hasil yang diperoleh selama proses pengamatan.
\end{abstract}

Kata kunci: ikan asap, pengemasan vakum, penyimpanan

\section{PENDAHULUAN}

Ikan asap merupakan salah satu produk olahan yang digemari konsumen baik di Indonesia maupun di mancanegara karena rasanya yang khas dan aroma yang sedap spesifik. Proses pengasapan ikan di Indonesia masih dilakukan secara tradisional menggunakan peralatan yang sederhana. selain itu kurang memperhatikan aspek sanitasi dan hygienis sehingga dapat memberikan dampak bagi kesehatan dan lingkungan. Kelemahankelemahan yang ditimbulkan oleh pengasapan tradisional antara lain kenampakan kurang menarik (hangus sebagian), kontrol suhu sulit dilakukan dan terjadi polusi udara (Swastawati ,2011).

Pengasapan didefinisikan sebagai proses penetrasi senyawa volatil pada ikan yang dihasilkan dari pembakaran kayu yang dapat menghasilkan produk dengan rasa dan aroma spesifik. Umur simpan yang lama karena adanya aktivitas anti bakteri, dalam menghambat aktivitas enzimatis pada ikan sehingga dapat mempengaruhi kualitas ikan asap. Senyawa kimia dari asap kayu umumnya berupa fenol (yang berperan sebagai antioksidan), asam organik, alkohol, karbonil, hidrokarbon dan senyawa nitrogen seperti nitro oksida, aldehid, keton, ester, eter, yang menempel pada permukaan dan selanjutnya menembus ke dalam daging ikan (Isamu dkk, 2012).

Ikan cakalang fufu yang diproduksi di Sulawesi utara ditemukan dipasaran terdapat dua bentuk, yaitu utuh dan yang di jepit dengan bambu. Jika ukuran ikan cakalang berukuran berat $>1,5 \mathrm{Kg}$ ikan diolah menjadi ikan cakalang fufu jepit (gepe), Sedangkan ikan dengan berat $<1,5 \mathrm{Kg}$ akan diolah atau difufu dalam bentuk utuh. Ikan cakalang fufu jepit 
banyak mendapat perhatian dari para ahli untuk di teliti, untuk ikan cakalang fufu utuh masih jarang diteliti padahal ikan cakalang utuh mempunyai beberapa kelebihan dibandingkan dengan ikan cakalang fufu jepit (gepe). Kelebihan ikan cakalang fufu utuh adalah sebagai berikut: tidak mengalami pewarnaan, waktu proses penanganan lebih singkat sehingga mutu bahan baku tidak menurun, Serta biaya produksi lebih rendah.

Menurut Renate, (2009) pengemasan dengan menggunakan plastik secara vakum dapat mengurangi jumlah oksigen dalam kemasan, mencegah kontaminasi mikroorganisme, dan memperpanjang umur simpan produk pangan. Selain itu kemasan vakum juga memberikan efek visual yang baik bagi makanan. Sifat-sifat permeabilitas. kemasan plastik ini akan mempengaruhi produk yang akan disimpan secara vakum.

\section{METODOLOGI PENELITIAN}

\section{Tempat dan waktu pelaksanaan penelitian}

Penelitian ini dilaksanakan di Laboratorium Pengendalian Mutu Hasil Perikanan, Fakultas Perikanan dan Ilmu Kelautan Universitas Sam Ratulangi Manado, waktu pelaksanaan selama 8 bulan dari penyusunan proposal sampai dengan ujian hasil penelitian.

\section{Bahan dan alat penelitian}

Bahan yang digunakan dalam penelitian ini adalah ikan cakalang asap utuh yang di beli di pasar bahu Malalayang Manado. Bahan Plastik Polyetilen (Kris) (Size $28 \times 40 \mathrm{~cm}$ ), bahan kimia yang di gunakan adalah $\mathrm{K}_{2} \mathrm{CO}_{3}$ jenuh, TCA 7,5\%, Larutan Indikator (methyl red dan bromo cresol green), Asam borat $\left(\mathrm{H}_{3} \mathrm{BO}_{3}\right)$, Asam Klorida ( $\mathrm{HCL}$ $0,02 \mathrm{~N}$ ), Vaselin, Nutrient Agar (NA), aquades, $\mathrm{NaCl} 0,9, \mathrm{pH} 7$, dan akuades.

Alat-alat yang digunakan dalam penelitian ini antara lain adalah : timbangan analitik, oven, Erlenmeyer, Magnetic stirrer, tabung reaksi, spatula, pipet steril, beaker glass, gelar ukur, cawan petri, autoclave, laminar flow, incubator, wadah penyimpanan/piring, pisau, tissue, mortar, pH-meter, beaker glass, gelas ukur, kertas saring whatman no.2, cawan conway, pipet, inkubator, corong kaca, cawan porselin, alat penjepit, desikator, silika gel, oven, dan mikroburet.

\section{Metode penelitian}

Metode yang digunakan dalam penelitian ini adalah metode Eksploratif deskriptif, yaitu mengumpulkan data fakta yang telah tersedia dilapangan melalui pencatatan dan pengamatan secara terperinci kemudian dilakukan analisa data berdasarkan data kualitatif dan data kuantitatif. Parameter yang di uji adalah kadar air, pH, TVBN, dan Organoleptik.

\section{Teknik pengambilan sampel}

Sampel yang digunakan dalam penelitian ini adalah ikan cakalang asap utuh, dibeli di pasar Bahu Kecamatan Malalayang Manado. Jumlah ikan yang di butuhkan dalam penelitian ini berjumlah 8 ekor. 4 ekor dikemas plastik tapi tidak vakum dan 4 ekor lagi di kemas vakum. Waktu penyimpanan adalah 0 , dan 2 , hari. Selanjutnya dilakukan analisa kadar Air, $\mathrm{pH}$, Total Volatile Base Nitrogen (TVB-N) dan Organoleptik

\section{Perlakuan}

Perlakuan pada penelitian ini adalah pengemasan dan lama penyimpanan, dengan $2 \mathrm{x}$ ulangan.

A. Perlakuan pengemasan

A1. Pengemasan plastik Vakum

A2. Pengemasan plastik tidak Vakum

\section{B. Lama penyimpanan}

Lama penyimpanan ini sebelumnya pada penyimpanan $0,2,4$, dan 6 hari dengan harapan hari ke 4 ikan cakalang asap utuh yang dikemas vakum masih dapat di konsumsi. Berdasarkan hasil penelitian pendahuluan ternyata ikan cakalang asap utuh hanya bertahan sampai 2 hari baik ikan vakum maupun non vakum untuk penyimpanan pada suhu ruang, sehingga penelitian lanjutan ditetapkan lama penyimpanan hanya 0 hari (B1) dan 2 hari (B2)

Pengamatan : Adapun Parameter Yang Di Amati Dalam Penelitian Ini Adalah Kadar Air, pH, TVB$\mathrm{N}$ dan Organoleptik.

\section{HASIL DAN PEMBAHASAN}

\section{Kadar Air}

Kadar air ikan cakalang (Katsuwonus pelamis L.) asap utuh yang dikemas vakum pada penyimpanan 0 hari memiliki nilai tertinggi yaitu $68.1 \%$ dan non vakum $63.3 \%$ sedangkan pada penyimpanan 2 hari mengalami penurunan untuk ikan yang divakum memiliki nilai $65.6 \%$ dan untuk ikan yang dikemas non vakum yaitu $63.3 \%$. penurunan kadar air kemungkinan besar karena adanya penguapan. Untuk ikan olahan seperti ikan asap kadar air adalah sekitar 60\%, kadar air berdasarkan Standar Nasional Indonesia untuk ikan asap. Tingginya kadar air dapat menyebabkan pertumbuhan mikroorganisme penyebab 
pembusukkan. Pengaruh kadar air sangat penting dalam menentukan mutu suatu bahan pangan. (Buckle 1987). Penyimpanan pada suhu ruang dengan suhu yang tidak terkontrol dapat mempengaruhi naik turunnya kadar air pada produk yang dikemas vakum.

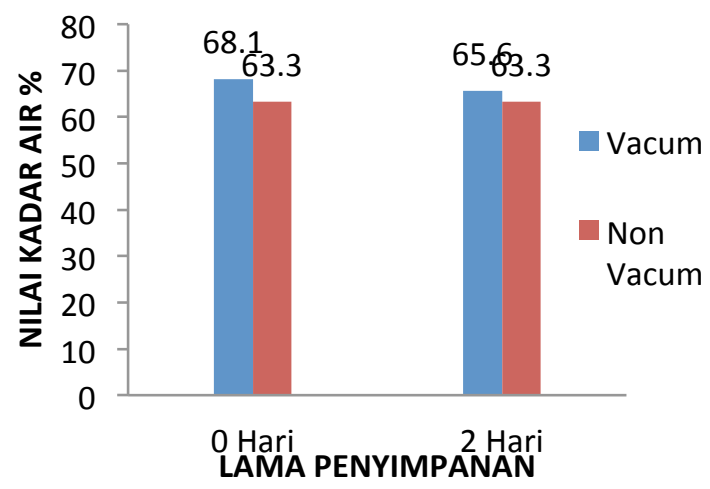

Gambar 1. Nilai Kadar Air ikan Cakalang

(Katsuwonus pelamis L.) asap selama 2 hari penyimpanan pada suhu ruang.

\section{Derajat Keasaman (pH)}

Nilai $\mathrm{pH}$ untuk lama penyimpanan 0 hari ikan yang dikemas vakum 5.68 dan non vakum 5.85 sedangkan untuk penyimpanan 2 hari mengalami peningkatan yaitu untuk ikan yang divakum 6.12 dan non vakum 6.08. Dari histogram diatas terlihat bahwa selama penyimpanan ikan asap utuh yang dikemas vakum dan non vakum mengalami peningkatan nilai $\mathrm{pH}$ pada hari ke 2 . Daging ikan yang mempunyai nilai $\mathrm{pH}$ tinggi disebabkan karena timbulnya senyawa-senyawa yang bersifat basa seperti amoniak, trimetilamin, dan senyawa-senyawa volatile lainnya yang juga dapat menurunkan nilai organoleptik dari produk (Hadiwiyoto 1993).

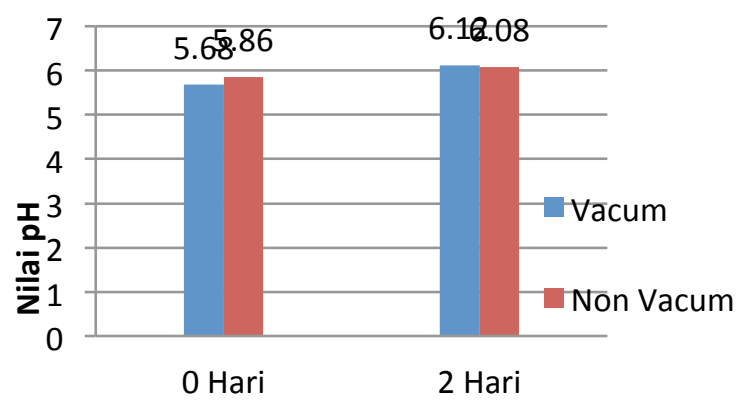

Lama Penyimpanan

Gambar 2. Nilai pH ikan Cakalang (Katsuwonus pelamis L.) Asap selama 2 hari penyimpanan pada suhu ruang.

\section{Analisis Total Volatile Base - Nitrogen (TVB-N)}

Data menunjukkan bahwa nilai TVB-N pada produk ikan asap selama penyimpanan 0 hari, untuk ikan yang dikemas vakum $39.9 \mathrm{mg} \mathrm{N} / 100 \mathrm{gr}$ dan $35.7 \mathrm{mg} \mathrm{N} / 100 \mathrm{gr}$ untuk yang non vakum sedangkan untuk penyimpanan selama 2 hari yaitu untuk ikan yang dikemas vakum adalah $85.3 \mathrm{mg}$ $\mathrm{N} / 100$ gr dan untuk yang non vakum $58 \mathrm{mg}$ N/100 gr. Dari data di atas menunjukan bahwa produk yang dikemas vakum dan non vakum selama 2 hari penyimpanan terjadi kenaikan nilai TVB-N. Kemungkinan kenaikan nilai TVB-N ini diakibatkan oleh tingkat kesegaran ikan yang kurang baik, selain itu ikan yang digunakan juga adalah ikan cakalang asap utuh yang tidak disiangi, dan adanya penyimpanan pada suhu ruang. Menurut Yunizal dkk (1994), nilai TVB-N tergantung pada mutu kesegaran ikan, makin mundur mutu ikan kadar TVB-N akan meningkat jumlahnya.

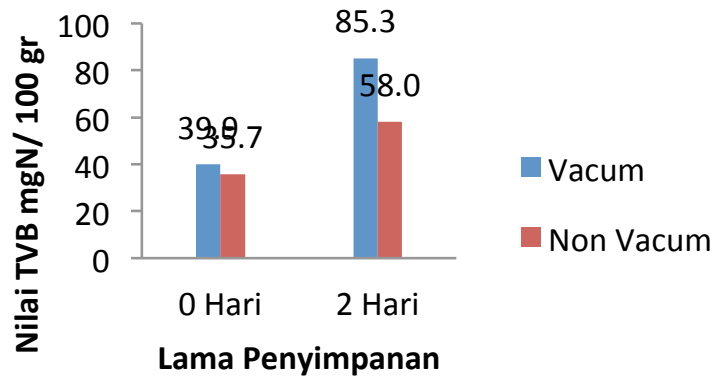

Gambar 3. Nilai Kadar Air ikan Cakalang (Katsuwonus pelamis L.) asap selama 2 hari penyimpanan pada suhu ruang.

\section{Total Plate Count (TPC)}

Data menunjukkan bahwa nilai TPC pada produk yang tidak di vakum selama penyimpanan pada hari ke 2 mengalami peningkatan dan memiliki nilai tertinggi yaitu $\left(2,46 \times 10^{3}\right)$ yang menunjukan peningkatan bakteri. Sedangkan nilai terendah ada pada produk yang dikemas vakum pada penyimpanan 0 hari yaitu $\left(4,95 \times 10^{2}\right)$. Dari data diatas dapat dilihat bahwa pada produk yang dikemas vakum terlihat lebih baik karena lebih sedikit koloni bakteri yang tumbuh dibanding produk yang non vakum. 


\subsection{Pengujian Organoleptik}

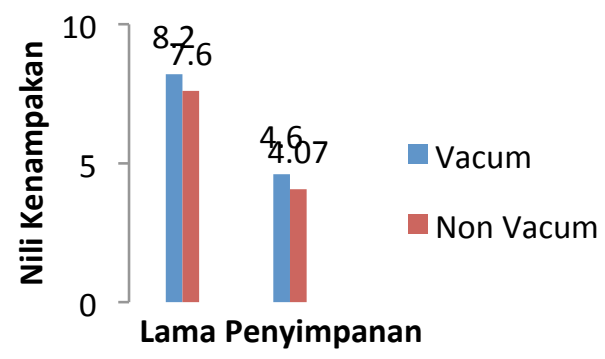

Gambar 4. Hasil penilaian panelis terhadap nilai organoleptik (Kenampakan) Ikan Cakalang (Katsuwonus pelamis L.)Asap utuh selama penyimpanan 2 hari pada suhu ruang.

Data menunjukkan bahwa nilai kenampakan pada penyimpanan 0 hari untuk ikan yang dikemas vakum 8.2 dan yang untuk non vakum 7.6 sedangkan untuk lama penyimpanan selama 2 hari mengalami penurunan nilai kenampakan yaitu untuk ikan yang divakum 4.6 dan non vakum 4.07. Hal ini semakin lama penyimpanan maka nilai produk semakin menurun. Dari data diatas menunjukkan bahwa penyimpanan dengan cara divakum dapat mempertahankan nilai kenampakan tetapi masih kurang maksimal karena produk disimpan pada suhu ruang yang suhunya kurang terkontrol.

\section{Bau}

Nilai bau produk pada vakum dan non vakum tidak berubah pada penyimpanan 0 hari, sedangkan perubahan nilai bau mengalami penurunan yang sangat nampak pada penyimpanan selam 2 hari. Hal ini berarti terjadi penurunan nilai bau selama proses penyimpanan.

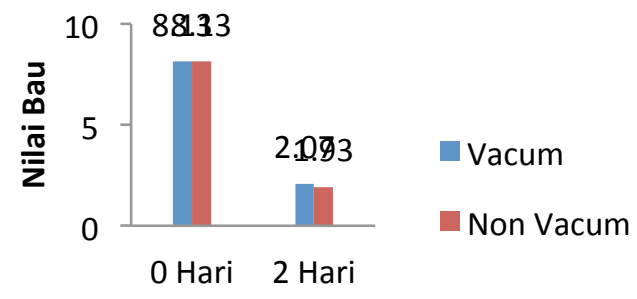

Lama Penyimpanan

Gambar 5. Hasil penilaian panelis terhadap nilai organoleptik (Bau) Ikan Cakalang (Katsuwonus pelamis L.)Asap utuh selama penyimpanan 2 hari pada suhu ruang.
Terjadinya penurunan nilai organoleptik selama penyimpanan kemungkinan karena bau khas ikan yang diasapi semakin berkurang. pada ikan yang dikemas vakum dan non vakum yang disimpan selam 2 hari.

\section{Rasa}

Data menunjukan bahwa nilai rasa produk ikan cakalang asap utuh yang disimpan pada 0 hari, untuk ikan yang dikemas vakum memiliki nilai tertinggi yaitu 8.4 dan yang non vakum sedikit lebih rendah yakni memiliki nilai 7.93. sedangkan untuk produk yang disimpan selama 2 hari mengalami penurunan tingkat kesukaan pada untuk produk yang di vakum memiliki nilai 2.13 , sedangkan untuk nilai produk non vakum lebih renda yaitu 1.4. Ini berarti nilai rasa produk semakin berkurang seiring lamanya penyimpanan. Hal ini terjadi karena tingkat kesegaran ikan yang semakin berkurang karena lama proses penyimpanan , pada suhu ruang yang tidak terkontrol. sehingga mempengaruhi cita rasa produk.

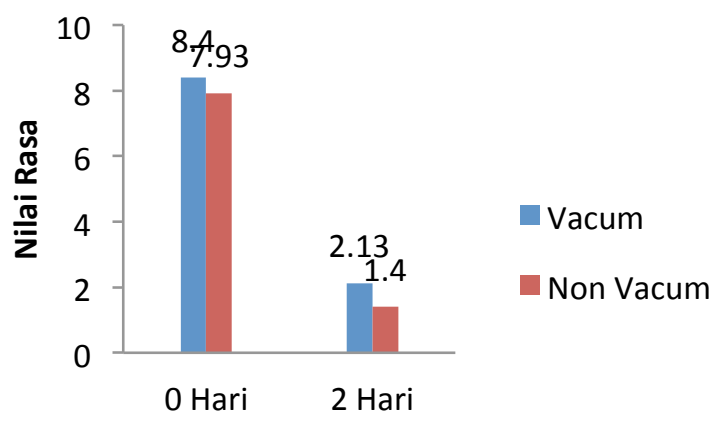

Lama Penyimpanan

Gambar 6. Hasil penilaian panelis terhadap nilai organoleptik (Rasa) Ikan Cakalang (Katsuwonus pelamis L.)Asap utuh selama penyimpanan 2 hari pada suhu ruang.

\section{Tekstur}

Data menunjukkan bahwa nilai tekstur pada penyimpanan 0 hari untuk ikan yang divakum memiliki nilai tertinggi yaitu 8.4 dan non vakum 7.5 sedangkan nilai terendah adalah pada penyimpanan selama 2 hari yaitu untuk ikan yang di vakum memiliki nilai 5.1 dan yang non vakum dalah 4.8. ini barati nilai tekstur menurun terjadi selama penyimpanan pada suhu kamar. Tingkat kesegaran ikan yang digunakan sebelum proses pengasapan juga dapat mempengruhi tekstur produk yang akan diolah. 


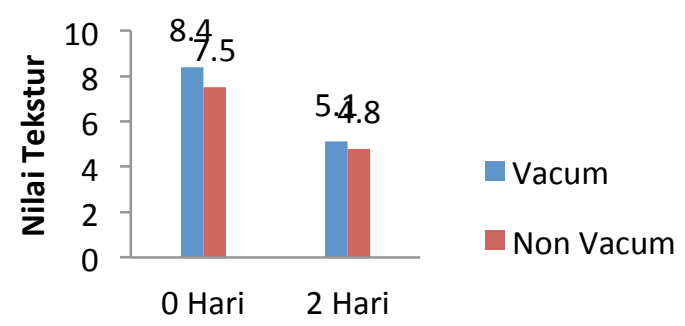

Lama Penyimpanan

Gambar 7. Hasil penilaian panelis terhadap nilai organoleptik (Tekstur) Ikan Cakalang

(Katsuwonus pelamis L.)Asap utuh selama penyimpanan 2 hari pada suhu ruang.

\section{KESIMPULAN}

Dari hasil penelitian dan pembahasan yang telah diuraikan maka dapat diambil beberapa kesimpulan sebagai berikut :

1. Nilai kadar air ikan cakalang (Katsuwonus pelamis L.) asap utuh yang dikemas vakum pada penyimpanan 0 dan 2 hari memiliki nilai yang sudah tidak di rekomendasikan oleh SNI karena memiliki nilai yang tinggi dimana ikan yang divakum dan non vakum pada 0 hari adalah $68.1 \%$ dan non vakum $63.3 \%$. Adapun pada penyimpanan hari ke 2 mengalami penurunan yang terjadi kemungkinan adanya penguapan terhadap suhu ruang yang tidak terkontrol namun masih berada diatas nilai yang tidak di rekomendasikan SNI. Tinggi nya kadar air ini juga kemungkinan adanya pengaruh pengasapan karna pengolah tidak memperhatikan lama pengasapan sehingga ikan masih dalam keadan kurang kering kemudian dipasarkan.

2. Nilai pH ikan cakalang (Katsuwonus pelamis L) asap utuh yang disimpan dengan pengemas vakum untuk 0 hari masi baik yaitu 5.68 ,dan untuk non vakum 5.85 mulai mengalami peningkatan nilai yang kurang baik. sedangkan untuk nilai $\mathrm{pH}$ pada hari ke 2 yaitu sudah masuk kriteria tidak baik karna merupakan media yang baik untuk berkembangnya bakteri untuk vakum 6.12 dan untuk non vakum adalah 6.08 .

3. Nilai TVB-N ikan cakalang (Katsuwonus pelamis $L$ ) asap utuh yang disimpan dengan pengemas vakum dan non vakum untuk 0 hari yaitu, vakum $39.9 \mathrm{mg}$ N/100 gr dan non vakum $35.7 \mathrm{mg} \mathrm{N} / 100$ gr. sedangkan untuk penyimpanan pada 2 hari mengalami kenaikan yaitu, vakum $85.3 \mathrm{mg} \mathrm{N} / 100$ gr dan non vakum $58 \mathrm{mg} \mathrm{N} / 100$ gr. Hasil ini menunjukan adanya peningkatan nilai TVB-N ini kemungkinan adanya ikan yang diolah menjadi ikan cakalang asap utuh sudah tidak segar atau sudah beberapa hari di asapi kemudian dipasarkan sehingga sangat berpengaruh terhadap kemunduran mutu dan nilai TVB-N.

4. Nilai TPC ikan cakalang (Katsuwonus pelamis $L$ ) asap utuh yang disimpan dengan pengemas vakum dan non vakum untuk 0 yaitu vakum $49,5 \times 10^{1}$ dan non vakum $74,5 \times 10^{3}$. sedangkan untuk nilai TPC pada hari ke 2 yaitu, vakum $145 \times 10^{1}$ dan non vakum $246,5 \times 10^{1}$. meningkatnya nilai TPC ini terjadi karena bertumbunya bakteri pembusuk yang mengakibatkan ikan mengalami penurunan mutu dengan cepat dan kemungkinan terjadi kenaikan nilai TPC karena ikan yang digunakan adalah ikan cakalang asap utuh dimana seluru bagian yang menjadi tempat utama pertumbuhan bakteri akan sangat cepat.

5. Berdasarkan hasil uji organoleptik ikan cakalang (katsuwonus pelamis L) asap utuh yang dikemas vakum dan non vakum di uji dari segi kenampakan, rasa, dan bau, ikan cakalang asap yang dikemas vakum dan non vakum pada penyimpanan 0 hari memiliki nilai yang baik, sedangkan untuk pengujian hari ke 2 memiliki penurunan nilai yang sudah tidak baik dan tidak direkondasikan untuk di konsumsi.

6. Penyimpanan ikan cakalang asap utuh dengan menggunakan plastik vakum memiliki nilai lebih baik untuk penyimpanan pada suhu ruang. Sedangkan untuk penyimpanan pada suhu ruang dengan menggunakan plastik tanpa divakum tidak di rekomendasikan untuk ikan cakalang asap utuh.

\section{DAFTAR PUSTAKA}

Afrianto dan Liviawaty. 1989. Pengawetan dan Pengolahan Ikan. Jogja: Penerbit Kanisius.

Badan Standarisai Nasional, 2006. Standar Nasional Indonesia 01-2346 uji

Organoleptic Ikan Segar.Jakarta; badan standarisasi nasional Indonesia.

Berhimpon, S., H. Dien, R. Montolalu, 2002. Processing and The Prospect of Katsuobushi (Ikan kayu) of North Sulawesi, Indonesia: A Review. Fish Handling and Processing Laboratory.Faculty of Fisheries and Marine Science.Sam Ratulangi University. Manado

Buckle, 1987. Ilmu pangan. Penerjemah Hari purnomo, adiyono, (Ui-prets) jakarta

Elias, S. 1983. Teknologi Refrigerasi Hasil Perikanan , Jilid 1 Teknik Pendinginan Ikan, Jakarta CV Paripurna. Skripsi.Tidak di terbitkan FPIK Unsrat Manado. 
Fardias, S., 1982. Mikrobiologi pangan. Penuntun Praktek Laboratorium Institut Teknologi Pertanian.

Haeldman. 2007. Handbook Of Food Engineering Second Edition (Edisi Terjemahan). Jakarta: Gramedia.

Heruwati, Endang Sri. 2002. Pengolahan ikan secara tradisional: prospek dan peluang pengembangan. Pusat riset pengolahan produk dan sosial ekonomi kelautandan perikanan, Jakarta.

Hadiwiyoto. 1993. Teknologi pengolahan hasil perikanan. Jilid 1 Liberti. Yogyakarta

Isamu Kobajashi T. Hari Purnomo dan Sudarminto S. Yuwono. 2012. Karakteristik Fisik, Kimia, Dan Organoleptik Ikan Cakalang (Katsuwonus Pelamis) Asap Di Kendari.

Isamu Kobajashi T. Hari Purnomo Dan Sudarminto S. Yuwono. 2012. Karakteristik Fisik, Kimia, Dan Organoleptik Ikan Cakalang (Katsuwonus Pelamis) Asap Di Kendari.Jurnal Teknologi Pertanian Vol. 13 No. 2 [Agustus 2012] 105-110

Kementrian kelautan dan perikanan 2011. Data indicator kerja umum tahun 2010. Jakarta: pusat data statistik dan informasi kementrian kelautan dan perikanan.

Mareta, Dea Tio., A, Nur Shofia. 2011. Pengemasan Produk Sayuran dengan Bahan Kemas Plastik pada Penyimpanan Suhu Ruang dan Suhu Dingin.Jurnal Mediagro

Munandar. 2009. Kemunduran Mutu IKan Nila Pada Penyimpanan suhu rendah.Universitas Sultan Ageng Tirtayasa.Serang.

Moedjiharo, 2004. Hubungan kadar air dengan mutu ikan, Teknologi industri hasil perikananfakultas perikanan dan ilmu kelautan universitas brawijaya malang https://daniwara.wordpress.com/laporan-tfpp/. Laporan TFPP

Murniyati, A. S dan Sunarman. 2000. Pendinginan, Pembekuan Dan Pengawetan Ikan. Penerbit Kanisius. Yogyakarta.Makalah. http://adecovilia.blogspot.com/2013/10/makalahpengolahan-pengasapan-ikan.html

Molejanto, 1982. Pengolahan dan Pengawetan Hasil Perikanan. Penebar Swadaya. Jakarta. Skripsi.

Moeljanto, R. 1992. "Pengawetan dan Pengolahan Hasil Perikanan". Penerbit Swadaya. Jakarta.

Nurul,hidayat, 2013. Klasifikasi ikan cakalang. Mei 27, 2015

http://www.nurulhidayat.com/2013/05/klasifikasiikan-cakalang.html

Rustamaji. 2009. Presentasi kadar air dan TMA. BFirst. Jakarta

Renate, Dharia. 2009. Pengemasan Puree Cabe Merah dengan Berbagai Jenis Plastik Yang Dikemas Vakum ( Packaging of Red Chilli Puree with Various Types of Plastic vacum Packaged ). Jurnal Teknologi Industri dan Hasil Pertanian.

Rompon, S. 2002. Tingkat ketengikan ikan kakatua (Callyodon $s p$ ) asin bebrapa pasar di manado. Skripsi, tdak di publikasikan. FPIK UNSRAT. Manado.
SNI, 2013 Pengolahan Pengasapan Ikan. http://adecovilia.blogspot.com/2013/10/makalahpengolahan pengasapan-ikan.html

Swastawati, Fronthea. 2011. Studi Kelayakan Dan Efisiensi Usaha Pengasapan Ikan Dengan Asap Cair Limbah Pertanian. Fakultas Perikanan Dan Ilmu Kelautan Universitas Diponegoro. Semarang.

Standard Nasional Indonesia (SNI), 2009. Ikan Asap Bagian 3. Spesifikasi.SNI 27 25.1:2009. Badan Standardisasi Nasional. Jakarta.

Suwetja, I. K, J. Pongoh, O. Jumariah 2007. Penentuan rigormortis TMAO dan ATP.Diklat; Universitas Sam Ratulangi.

Sasmito,B.B. 2006. Dasar - dasar Pengawetan Bahan Pangan. Univarsitas Brawijaya. Malang.

Suwetja, I. K. 1993. Metode Penentuan Mutu Ikan. Jilid I. Penentuan Kesegaran. Fakultas Perikanan dan Ilmu Kelautan. Universitas Sam Ratulangi. Manado

Soekarto, S, T. 1990 .Penilaian Organoleptic Untuk Industry Pangan Dan Hasil Pertanian. Jakarta, Bharata karya Aksara.Skripsi.

Soeseno, 1985. Teknik Penangkapan Dan Teknologi Ikan. Yasaguna Jakarta. Skripsi.

Sakidja, 1985,Dasar-Dasar Pengawetan Makanan, Badan Kerjasama Perguruan Tinggi Negri Indonesia Bagian Timur Unjung Pandang.

Sudarmadji, S. Bambang Haryono, Suhardi, 1984. Prosedur Analisa Untuk Bahan Makanan dan Pertanian.

Saanin, 1984.Taksonomi dan kunci identifikasi ikan. Bina cipta, Jakarta. Skripsi

Tapatubun, dkk, 2000. Hubungan kadar air dengan mutu ikan. https://daniwara.wordpress.com/laporantfpp/ . Laporan TFPP

Tampubolon, 1983. Tuna dan penenganannya. fakultas pertanian IPB Bogor.

Puspabuana, O M. 2013. Pengolahan pengasapan ikan.

http://adecovilia.blogspot.com/2013/10/makalahpengolahan-pengasapan-ikan.html.

Purnomo,H., 1995 Aktivitas Air dan Peranannya dalam pengawetan Pangan. UI Press. Malang.

Winarno, F, G. 2002. Hubungan kadar air dengan mutu ikan. https://daniwara.wordpress.com/laporan-tfpp/. Laporan TFPP

Wibowo, 2000. Industri pengasapan ikan. Penabar Swadaya. Jakarta. Skripsi.

Winarno, F, G. 1993. Pangan (Gizi teknologi dan Konsumen). Gramedia Pustaka Utama. Skripsi.

Yulstiani, Ratna. 2008. Monograf Asap Cair Sebagai Bahan Pengawet Alami Pada Produk Daging Dan Ikan. Upn Veteran Jawa Timur. Makalah

Yunianto, 2003.Teknik Penanganan Ikan. Jakarta, penebar swadaya. Skripsi

Yunizal, 1998 Penanganan ikan segar. Jakarta. Instalasi penelitian perikanan Laut sipil. 